\title{
Effects of irrigation and nitrogen fertiliser on the growth and nutrient relations of Prunus avium $L$ and 'Colt' (Prunus avium x Prunus pseudocerasus) in the nursery and after transplantation
}

\author{
NA Hipps, KH Higgs, LG Collard, TJ Samuelson \\ Horticulture Research International, Perennial Crops Department, \\ East Malling, Kent ME19 6BJ, UK
}

(Received 18 January 1993; accepted 8 June 1994)

\begin{abstract}
Summary - One-year-old seedlings of Prunus avium and hardwood cuttings of 'Colt' were lined out and nitrogen fertiliser was applied at rates of between 0 and $9 \mathrm{~g}$ per tree either with or without irrigation. Nitrogen fertiliser had no effect on the growth and leaf mineral concentrations of either genotype. Irrigation increased the growth of both genotypes and the concentrations of $P$ and $K$ in the leaves but the concentrations of $\mathrm{Mg}$ and $\mathrm{Ca}$ were reduced. The following year the trees were lifted and replanted. The plants of 'Colt' that had previously received irrigation produced longer total shoot lengths than unirrigated plants, whereas there was no difference for $P$ avium. The residual effect of irrigation slightly reduced the concentration of $P$ in the leaves of both genotypes, yet the concentrations of $\mathrm{N}, \mathrm{K}, \mathrm{Ca}, \mathrm{Mg}$ and $\mathrm{Mn}$ were unaffected.
\end{abstract}

Prunus / nutrition / nursery / transplant / growth

Résumé - Effets de l'irrigation et de la fertilisation azotée sur la croissance et la nutrition de Prunus avium et de "Colt" (Prunus avium x Prunus pseudocerasus) en pépinière et après transplantation. De jeunes semis de 1 an de Prunus avium et des boutures ligneuses du cultivar "Colt" (Prunus avium $X$ Prunus pseudocerasus) ont été plantés en ligne avec un faible espacement $(0,3 \mathrm{~m})$. Un engrais azoté a été appliqué à des niveaux variant de 0 à $9 \mathrm{~g}$ par arbre, avec ou sans irrigation. Pour les 2 types de Prunus, la fertilisation azotée n'a pas eu d'effet, ni sur la croissance, ni sur la concentration en éléments minéraux dans les feuilles. L'irrigation a augmenté la croissance et les concentrations en $P$ et $K$ dans les feuilles chez les 2 types de Prunus. En revanche, les concentrations en $\mathrm{Mg}$ et Ca ont été réduites. L'année suivante, les arbres ont été amachés et transplantés. Les plants de "Colt" qui avaient été précédemment irrigués ont produit alors une longueur totale de pousse plus importante que les plants non irrigués. Au contraire, pour Prunus avium, aucune différence n'est apparue. L'effet résiduel de l'irrigation a consisté en une réduction de la concentration en $P$ dans les feuilles pour les 2 types de Prunus, alors que les concentrations en N, K, Ca, Mg et Mn n'étaient pas affectées. 


\section{INTRODUCTION}

Nearly $90 \%$ of the UK's consumption of forest products is imported (Forest Industry Committee of Great Britain, 1987) and there is increased interest in the use of broadleaf trees as an alternative crop in lowland areas previously used for agriculture. Cherry is a very suitable native tree species for planting in these areas as it grows quickly, the timber has high value and is much in demand (Pryor, 1988).

Tree seedlings are likely to receive minimum soil management after planting into farmland due to their low values and long growth cycles compared with other agricultural or horticultural crops. Ideally, newly planted trees should establish well with rapid growth soon after outplanting. The quality of trees used for outplanting may be influenced by fertiliser application and irrigation in the nursery. Millard and Proe (1991) found that sycamore (Acer pseudoplatanus) seedlings grown in pots, and receiving a high rate of nitrogen in year 1 and a low rate in year 2 (after transplanting) were unable to sustain early leaf growth rates later in year 2 , whereas those seedlings receiving the treatments vice versa greatly increased their leaf growth later in year 2. Van de Driessche (1984) states that with coniferous seedlings the benefit of nursery fertilisation to survival after transplanting could not be consistently demonstrated. In several experiments (Knight, 1957; Switzer and Nelson, 1963; Bell, 1968; Mullin and Bowdery, 1978) no effect was shown but the survival and growth of outplanted Douglas fir Pseudotsuga menziesii (Mirbel) were increased by fertilisation which also increased seedling size (Smith et al, 1966). Little is known about the influence of irrigation on nursery tree seedling nutrient relations and even less information is available on the influence of irrigation on seedling nutrient relations and subsequent growth and survival after outplanting (Duryea and McClain, 1984).
This report investigates the interaction of nitrogen fertiliser and irrigation on the growth and nutrient relations of cherry seedlings and cuttings in the liner nursery and the subsquent performance after transplantation.

\section{MATERIALS AND METHODS}

\section{Site}

The trial was carried out at Horticulture Research international (HRI), East Malling, on a soil of the Barming Series (Furneaux, 1954), which has approximately $60-120 \mathrm{~cm}$ fine sandy loam overlying ragstone. Bare-rooted 1-year-old seedlings of Prunus avium and pre-rooted hardwood cuttings of 'Colt' taken from hedges in December 1988 were planted at the end of March 1989 in $\mathrm{N}-\mathrm{S}$ rows which were $1 \mathrm{~m}$ apart. Within the row each plot consisted of 10 trees spaced at $0.3 \mathrm{~m}$. The trees were lifted on 8 March 1990 and replanted in adjacent land on the same day, in a $\mathrm{N}-\mathrm{S}$ direction in rows $2 \mathrm{~m}$ apart. Within each row the trees were spaced $2 \mathrm{~m}$ apart. Cherry trees had not been grown in the soil previously so there was no risk of replant disease.

\section{Soil treatments}

The soil treatments were chosen considering the interaction of irrigation and nitrogen fertiliser. The fertiliser, ammonium nitrate, was applied at 4 rates, $0,3,6$ or $9 \mathrm{~g} \mathrm{~N}$ total per tree per year, either broadcast over a $3 \times 0.4 \mathrm{~m}$ strip along the row with split dressings on 9 May and 27 June 1989 or dissolved in water via trickle irrigation (fertigation) on alternate days over $100 \mathrm{~d}$ between early May and mid-August. On days that fertigation treatment was not applied, the relevant trees were irrigated. Fertigation or irrigation was applied at a rate of 1.7 I per tree per day.

in 1990 no nitrogen fertiliser was applied but half of the total number of transplanted trees (which represented all the previous years treatments) were trickle irrigated, 4 I per tree being given daily from April to October. 


\section{Experimental design}

In 1989 each plot contained 2 groups of experimental trees with guard trees between and at each end. One group contained 5 trees harvested during the year for growth and nutrient analysis. The other group contained 2 trees which were measured non-destructively during 1989 and then lifted and replanted so that the residual effects of the first year treatments could be measured after transplantation in 1990. Thus in 1990 each plot contained 2 trees.

In 1989 the experimental design was a $2 \times 2$ $\times 4$ factorial with 7 replicates of each treatment combination. Each replicate was a single row of 16 plots and within each replicate the 16 treatment combinations were arranged in 4 incomplete blocks of 4 plots. The allocation of treatment combinations to blocks was such that each of the 3 degrees of freedom of the variety $x$ nitrogen interaction and of the irrigation $x$ nitrogen and variety $x$ irrigation $x$ nitrogen interactions was confounded in 2 or 3 of the 7 replicates

In 1990 the experimental design was the same as in 1989 except that there was an additional treatment as 1 of each pair of trees in the original treatment was trickle irrigated.

\section{Tree growth}

Trees were harvested from each of the 16 plots in 1 replicate on 18 May, 12 June, 3 July, 31 July, 21 August and 18 September 1989. The trees were cut at ground level and records made of basal stem diameter and the number and length of shoots for each tree. The stems and leaves were separated and dried in an oven for $48 \mathrm{~h}$ at $85^{\circ} \mathrm{C}$ to determine dry matter weight.

Shoot lengths and stem diameters were measured on 21 February 1990 and 25 January 1991 on all the trees used for transplanting; these trees were lifted on 21 March 1991 and fresh weights recorded.

\section{Mineral analysis}

Leaf and stem samples from all the harvested trees were used for mineral analysis. Leaf samples were taken on 10 September 1990 only from the trees which had received 0 or $9 \mathrm{gN}$ in 1989 .
Analysis of the leaves was carried out after a Kjeldahl digestion in concentrated $\mathrm{H}_{2} \mathrm{SO}_{4}$ containing $0.1 \% \mathrm{Se}$ as a catalyst and $\mathrm{H}_{2} \mathrm{O}_{2}$. Nitrogen was determined on a Technicon Autoanalyzer using the indophol blue method and $P$ was determined using the molybdenum blue reaction. $\mathrm{K}$, $\mathrm{Ca}, \mathrm{Mg}$ and $\mathrm{Mn}$ were determined by atomic emission or absorption spectrophotometry.

Soil samples were taken from control plots on 18 May $1989, P$ was extracted with $0.5 \mathrm{M}$ $\mathrm{NaHCO}_{3}$ (pH 8.5), using $5 \mathrm{~g}$ soil in $100 \mathrm{ml}$ extractant (MAFF, 1981). Exchangeable $\mathrm{K}$ was determined by extraction of $10 \mathrm{~g}$ soil with $50 \mathrm{ml}$ of $1 \mathrm{M}$ $\mathrm{NH}_{4} \mathrm{NO}_{3}$ (MAFF, 1981). $\mathrm{NH}_{4}-\mathrm{N}$ and $\mathrm{NO}_{3}-\mathrm{N}$ were determined by extraction of $40 \mathrm{~g}$ moist soil with $200 \mathrm{ml}$ of $2 \mathrm{M} \mathrm{KCl}$ (MAFF, 1981). The soil characteristics are shown in table $\mathrm{I}$.

\section{RESULTS}

\section{Rainfall, soil moisture deficit and plant water status in 1989}

Total rainfall was $30 \%$ below average for the period April to September (table II). The maximum soil moisture deficit was $93 \mathrm{~mm}$ adjacent to the unirrigated trees and $43 \mathrm{~mm}$ for irrigated trees (table II). Drought stress was reduced by irrigation as leaf water potential and stomatal conductance were consistently increased (table III).

Table I. Soil chemical analysis.

$\frac{\text { Depth }}{0-15 \mathrm{~cm} \quad 15-30 \mathrm{~cm}}$

$\begin{array}{lcc}\mathrm{pH} & 7.6 & 7.4 \\ \begin{array}{l}\text { Extractable } \mathrm{P} \\ \left(\mu \mathrm{g} \mathrm{g}^{-1} \text { soil }\right)\end{array} & 25 & 24 \\ \begin{array}{l}\text { Extractable } \\ \left(\mathrm{K}_{\mu \mathrm{g} \mathrm{g}} \mathrm{g}^{-1} \text { soil }\right)\end{array} & 221 & 241 \\ \mathrm{NH}_{4}-\mathrm{N} \\ \begin{array}{l}\left(\mu \mathrm{g} \mathrm{g} \mathrm{g}^{-1} \text { soil }\right) \\ \mathrm{NO}_{3}-\mathrm{N}\end{array} & 2.1 & 3.8 \\ \left(\mu \mathrm{g} \mathrm{g}^{-1} \text { soil) }\right. & 24.3 & 16.0\end{array}$




\section{Plant growth and nutrient status before transplantation in 1989}

At planting the mean height and stem diameter were $61 \mathrm{~cm}$ and $5.6 \mathrm{~mm}$, respectively, for the 'Colt' cuttings and $35 \mathrm{~cm}$ and $3.4 \mathrm{~mm}$, respectively, for the $P$ avium seedlings. The differences between 'Colt' and $P$ avium in height $(P<0.001$, standard error of the difference (SED) $0.6 \mathrm{~cm}, 69 \mathrm{df}$ ) and stem diameter $(P<0.001$, SED $0.08 \mathrm{~mm}, 69 \mathrm{dt})$ were highly significant.

Nitrogen fertiliser had no influence on the measured growth parameters of either genotype and so the results presented here are averaged over the different nitrogen levels used. Irrigation increased the total new shoot length for both $P$ avium and 'Colt' (table IV); for $P$ avium, this was due to an increase in mean shoot length only, whereas for 'Colt' both mean shoot length and number of shoots per tree increased. In all cases 'Colt' had a shorter mean shoot length than $P$ avium.
Growth curves were fitted to the data collected from the trees harvested during the season. Gompertz curves were found to provide a satisfactory fit and parameters were estimated by minimizing the residual sum of squares on a log-transformed scale to allow for the increasing variance of the data over time. Fitted curves did not differ significantly between nitrogen levels for any of the variables.

Growth analysis of total shoot length (fig 1) showed that early increases in shoot length caused by irrigation persisted throughout the season and that the shoot extension of 'Colt' continued later than that of $P$ avium. The relative total shoot extension rates for each genotype (ie the average slope of the curves when plotted on a log scale) were similar.

\section{Dry matter}

At the first sampling date in May very little shoot growth had occurred and the mean

Table II. Monthly rainfall and maximum values of soil moisture deficit before (1989) and after (1990) transplanting.

\begin{tabular}{|c|c|c|c|c|c|c|c|}
\hline & \multirow{4}{*}{$\begin{array}{l}\text { Rainfall } 50 \text { years } \\
\text { average }(\mathrm{mm})\end{array}$} & \multicolumn{3}{|c|}{1989} & \multicolumn{3}{|c|}{1990} \\
\hline & & $\begin{array}{l}\text { Rainfall } \\
(\mathrm{mm})\end{array}$ & \multicolumn{2}{|c|}{$\begin{array}{l}\text { Maximum soil } \\
\text { moisture deficit } \\
(\mathrm{mm})^{*}\end{array}$} & $\begin{array}{l}\text { Rainfall } \\
(\mathrm{mm})\end{array}$ & \multicolumn{2}{|c|}{$\begin{array}{c}\text { Maximum soil } \\
\text { moisture deficit } \\
(m m)^{\star \star}\end{array}$} \\
\hline & & & \multicolumn{2}{|c|}{ Irrigation } & & \multicolumn{2}{|c|}{ Irrigation } \\
\hline & & & - & + & & - & + \\
\hline April & 44 & 85 & - & - & 40 & 27 & 20 \\
\hline May & 47 & 2 & 22 & 2 & 4 & 53 & 28 \\
\hline June & 46 & 40 & 26 & 7 & 55 & 57 & 45 \\
\hline July & 53 & 16 & 64 & 15 & 8 & - & - \\
\hline August & 57 & 26 & 93 & 34 & 26 & - & - \\
\hline September & 60 & 45 & 92 & 43 & 35 & 106 & 93 \\
\hline Total & 307 & 214 & & & 168 & & \\
\hline
\end{tabular}

" $20 \mathrm{~cm}$ from tree measured by neutron probe; ${ }^{\star *} 30 \mathrm{~cm}$ from tree measured by neutron probe. 
Table III. Main effect of irrigation on leaf potential and stomatal conductance before (1989) and after (1990) transplanting.

$\frac{\text { Leaf water potential (MPa) }}{\text { Irrigation }}+$ SED df

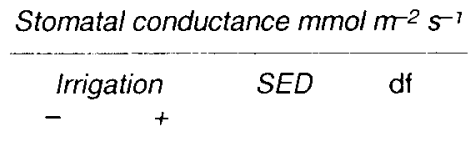

1989

24 May

15 June

6 July

28 July

14 September

25 September

1990

$\begin{array}{lllllllll}3 \text { May } & - & - & - & - & 67 & 96 & 3.0 & 96 \\ \text { 19 June } & -1.10 & -0.84 & 0.020 & 48 & 122 & 166 & 4.2 & 96 \\ \text { 12 July } & -1.16 & -1.00 & 0.017 & 96 & 173 & 227 & 6.2 & 96 \\ \text { 10 August } & -1.32 & -1.15 & 0.025 & 48 & 158 & 223 & 8.7 & 96 \\ \text { 29 August } & -1.26 & -1.16 & 0.018 & 48 & 190 & 244 & 7.1 & 96 \\ \text { 27 September } & -1.11 & -0.96 & 0.022 & 48 & 168 & 193 & 5.1 & 96\end{array}$

SED is standard error of the difference between two treatment means; $d f$ is degrees of freedom.

Table IV. The effect of irrigation applied in 1989 on the growth of $P$ avium and 'Colt' in 1989 and after transplantion in 1990.

Prunus

$\begin{array}{ll}-1.26 & -1.13 \\ -0.94 & -0.86 \\ -1.18 & -0.97 \\ -1.22 & -0.93 \\ -0.69 & -0.62 \\ -0.91 & -0.84\end{array}$

0.029

57

$100 \quad 145$

$216 \quad 224$

5.6

6.4

57

0.016

69

227

347

12.1

9.2

0.019

243

10.0

69

$244 \quad 261$

16.8

69

69

0.023

69

298

315

69

\author{
after transplantion in 1990.
}

$\frac{1989}{- \text { Irigation }}$ SED (69 df)

$\frac{1990}{+ \text { Irrigation }+}$

Total shoot length (m)

$P$ avium
'Colt'

Number of shoots per tree

$P$ avium

'Colt'

2.07
3.34

2.57
6.23

0.241

4.69

4.21
14.13

0.492

Mean shoot length (m)

$\begin{array}{lllllll}P \text { avium } & 0.52 & 0.71 & 0.034 & 0.41 & 0.35 & 0.023 \\ \text { 'Colt' } & 0.34 & 0.51 & & 0.59 & 0.42 & \end{array}$

Stem diameter ( $\mathrm{mm}$ )

$\begin{array}{lllllll}P \text { avium } & 13.4 & 15.4 & 0.71 & 25.2 & 25.9 & 0.78 \\ \text { 'Colt' } & 14.1 & 17.0 & & 30.0 & 32.9 & \end{array}$

Fresh weight $(\mathrm{g})$ at final lifting

$$
\text { 'Covium }
$$

44

0.5

$12 \quad 12$

$\begin{array}{ll}12 & 12 \\ 22 & 34\end{array}$

1.2

$\begin{array}{rrr}667 & 681 & 53.2 \\ 1297 & 1613 & \end{array}$


total aerial dry weights of 'Colt' and $P$ avium were 2.1 and $5.6 \mathrm{~g}$, respectively. Although the total aerial dry weight of 'Colt' was greater than that of $P$ avium during the growth period (fig 2), their maximum relative growth rates were similar at 0.050 and $0.046 \mathrm{~d}^{-1}$ for $P$ avium and 'Colt', respectively. Thus, differences in the total aerial dry matter weights of the 2 types of cherry at the final harvest were mainly due to the initial differences in size at planting. Irrigation increased dry matter accumulation for both cultivars.

\section{Leaf mineral concentrations}

Nitrogen fertiliser had no significant effect $(P>0.05)$ on the concentrations of N, P, K, $\mathrm{Ca}, \mathrm{Mg}$ and $\mathrm{Mn}$ in the leaves. Irrigation did not influence the concentration of $\mathrm{N}$ in the leaves of either genotype during the season (fig 3 ) but the concentrations of $\mathrm{P}$ and $\mathrm{K}$ were significantly $(P<0.05)$ increased by irrigation after June, whereas the concentrations of $\mathrm{Mg}$ and $\mathrm{Ca}$ were reduced $(P<$ $0.05)$. The total foliar content of minerals

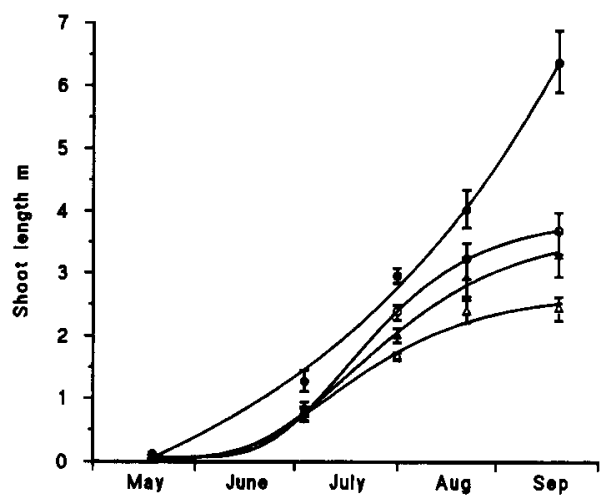

Fig 1. Fitted growth curves (Gompertz) showing the effect of irrigation on the total shoot length of $P$ avium and 'Colt' during 1989. Vertical bars are $\pm \mathrm{SE}(3 d f)$. $\triangle P$ avium - irrigation; $\Delta P$ avium + irrigation; $O$ 'Colt' - irrigation; 'Colt' + irrigation. was derived by multiplying mean leaf concentration by total leaf dry weight (ie combining data presented in figures 2 and 3 ). At the final harvest, there was a significant $(P<0.01)$ interaction between genotype and irrigation for the total foliar content of $\mathrm{Ca}$ and $\mathrm{Mg}$. The total foliar contents of $\mathrm{Ca}$ per plant of 'Colt' and $P$ avium were 1046 and $503 \mathrm{mg}$, respectively, for unirrigated trees and 1503 and $408 \mathrm{mg}$ (SED $47 \mathrm{mg}, 3$ $d f$ ), respectively, for irrigated trees. The total foliar contents of $\mathrm{Mg}$ per plant of 'Colt' and $P$ avium were 166 and $56 \mathrm{mg}$, respectively, for unirrigated trees and 242 and $47 \mathrm{mg}$ (SED $6 \mathrm{mg}, 3 \mathrm{df}$ ) respectively for irrigated trees.

In May, 'Colt' had significantly greater leaf concentrations of $\mathrm{N}(P<0.001), \mathrm{P}(P<$ $0.001), \mathrm{K}(P<0.05), \mathrm{Mg}(P<0.05), \mathrm{Ca}(P<$ $0.05)$ and $\mathrm{Mn}(P<0.01)$ than $P$ avium (fig 3$)$.

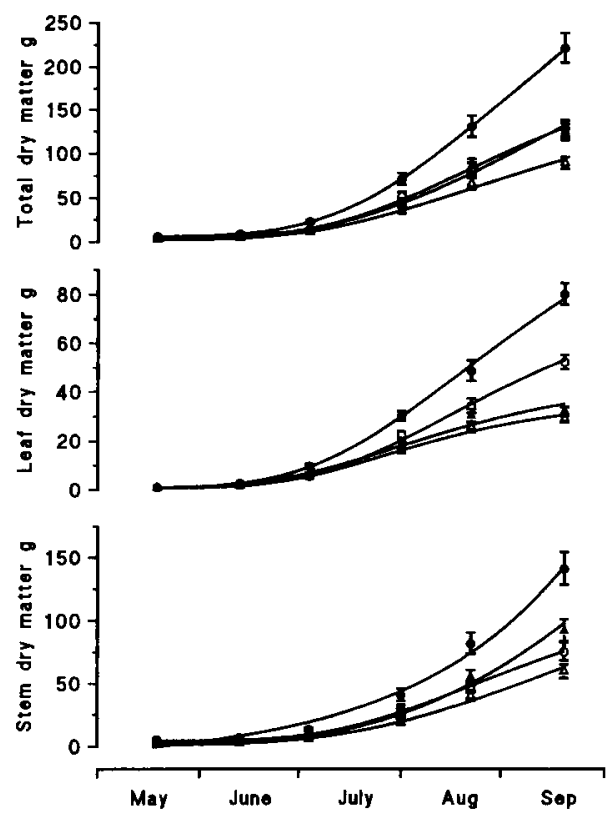

Fig 2. Fitted growth curves (Gompertz) showing the effect of irrigation on the total dry matter, leaf dry matter and stem dry matter during 1989. Vertical bars are $\pm \mathrm{SE}$. (3 df). $\triangle P$ avium - irrigation; $\triangle P$ avium + irrigation; $O$ 'Colt' - irrigation; 'Colt' + irrigation. 

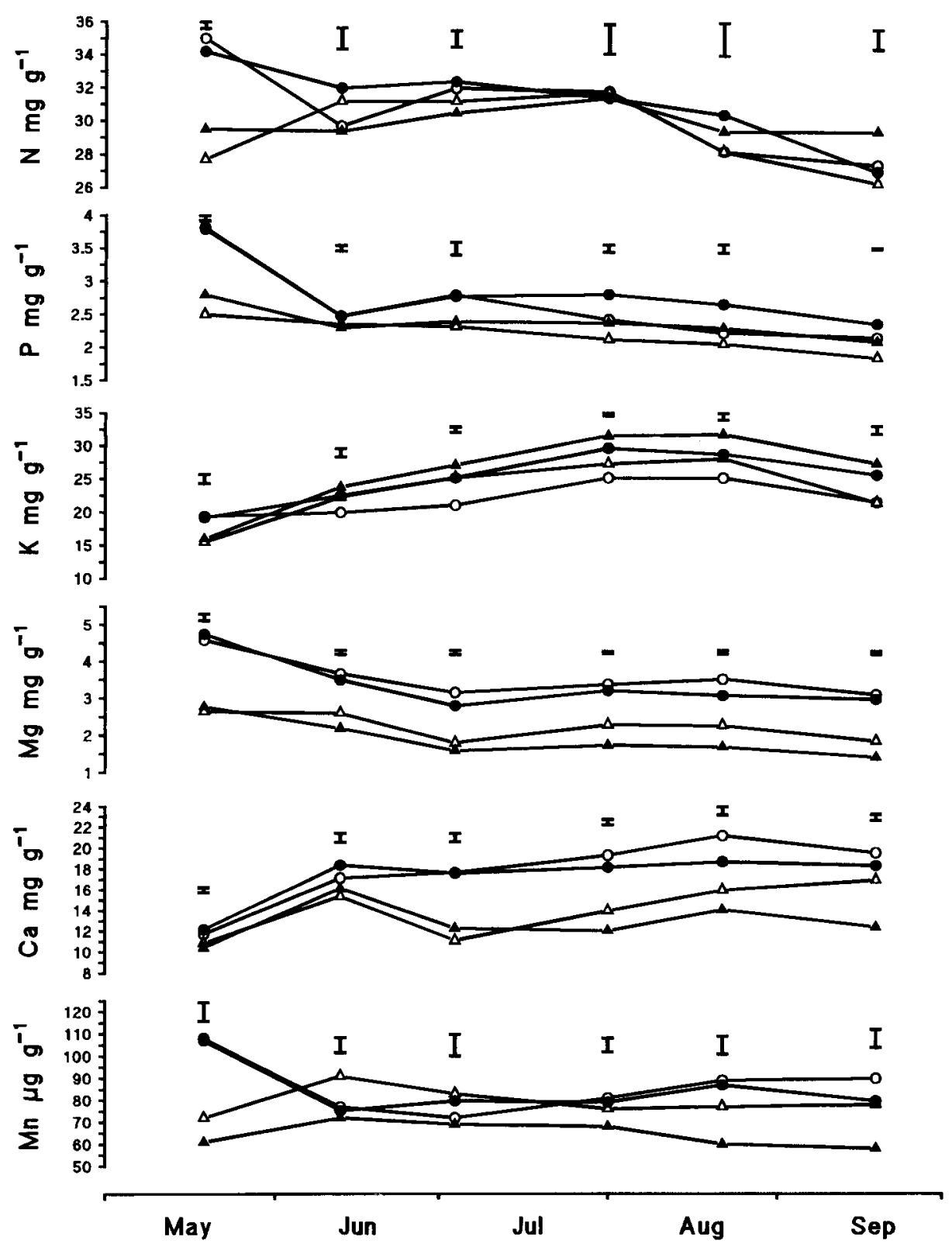

Fig 3. Seasonal time course in 1989 of the mineral concentrations in leaves of $P$ avium and 'Colt' in the 2 irrigation treatments. Vertical bars represent SED ( $3 d f) . \triangle P$ avium - irrigation; $\Delta P$ avium + irrigation; $\mathrm{O}$ 'Colt' - irrigation; 'Colt' + irrigation. 
For $\mathrm{Mg}$ and $\mathrm{Ca}$ these effects persisted during the whole season whereas for all the other minerals they did not. After June the mean concentration of $\mathrm{K}$ was greater in leaves of $P$ avium than 'Colt'.

- Leaves of $P$ avium showed some symptoms of $\mathrm{Mg}$ deficiency during the season which were characterised by an interveinal purple colour developing on the basal leaves followed by chlorosis and necrosis.

\section{Stem and shoot mineral concentrations}

Irrigation did not significantly $(P>0.05)$ influence the concentration of any of the minerals in the stem and shoots (fig 4).

Early in the season the concentrations of $\mathrm{N}$ and $\mathrm{Ca}$ in the stems and shoots of 'Colt' were greater than in $P$ avium. From May until the end of July the concentration of $\mathrm{K}$, $\mathrm{Mg}$ and $\mathrm{Mn}$ were significantly higher in the stems and shoots of $P$ avium than in those of 'Colt'.

\section{Rainfall, soil moisture deficit and plant water status in 1990}

Total rainfall was $45 \%$ below average for the period April to September (table II). The maximum soil moisture deficit was $106 \mathrm{~mm}$ adjacent to the unirrigated trees and $93 \mathrm{~mm}$ for irrigated trees (table II). Drought stress was consistently reduced by irrigation as leaf water potential and stomatal conductance were consistently increased (table III).

\section{Plant growth and nutrient status after transplantation in 1990}

Nitrogen fertiliser applied in 1989 had no residual effect on the growth of the trees in 1990. Irrigation in 1989 caused an increase in the total new shoot length and number of shoots of 'Colt' in the following year whereas for $P$ avium it had the opposite effect on new shoot length and no effects on number of shoots (table IV). Thus, the 1989 application of irrigation reduced the mean shoot length of both genotypes in 1990. 'Colt' had a significantly greater total new shoot length, number of shoots and mean new shoot length than $P$ avium $(P<$ 0.001).

The irrigation of the transplanted trees in 1990 (table V) significantly increased stem diameter $(P<0.01)$, total new shoot length $(P<0.001)$, number of shoots $(P<0.001)$ and mean shoot length $(P<0.001)$ for both genotypes.

\section{Leaf mineral analysis}

Nitrogen fertiliser applied in 1989 had no effect on the concentration of $\mathrm{N}$ in the leaves in 1990.

The residual effect of irrigation in 1989 (table VI) slightly but significantly decreased $P$ concentration in the leaves of both cultivars $(P<0.01)$ but the concentrations of the other minerals were unaffected.

The differences between genotype were similar to those found in the previous year, ie 'Colt' had a greater concentration of $P$ $(P<0.05)$, Ca $(P<0.001), \mathrm{Mg}(P<0.001)$ and $\mathrm{Mn}(P<0.001)$ in leaves than $P$ avium, but a lower concentration of $\mathrm{K}(P<0.001)$. Basal leaves of $P$ avium seedlings again showed some visual symptoms of $\mathrm{Mg}$ deficiency.

The irrigation of the transplanted trees in 1990 (table VII) had a large influence on the concentration of all the minerals in the leaves except $\mathrm{N} ; \mathrm{P}(P<0.001)$ and $\mathrm{K}(P<$ $0.01)$ were signifjcantly increased whereas $\mathrm{Ca}(P<0.01), \mathrm{Mg}(P<0.01)$ and $\mathrm{Mn}(P<$ $0.01)$ were reduced. 

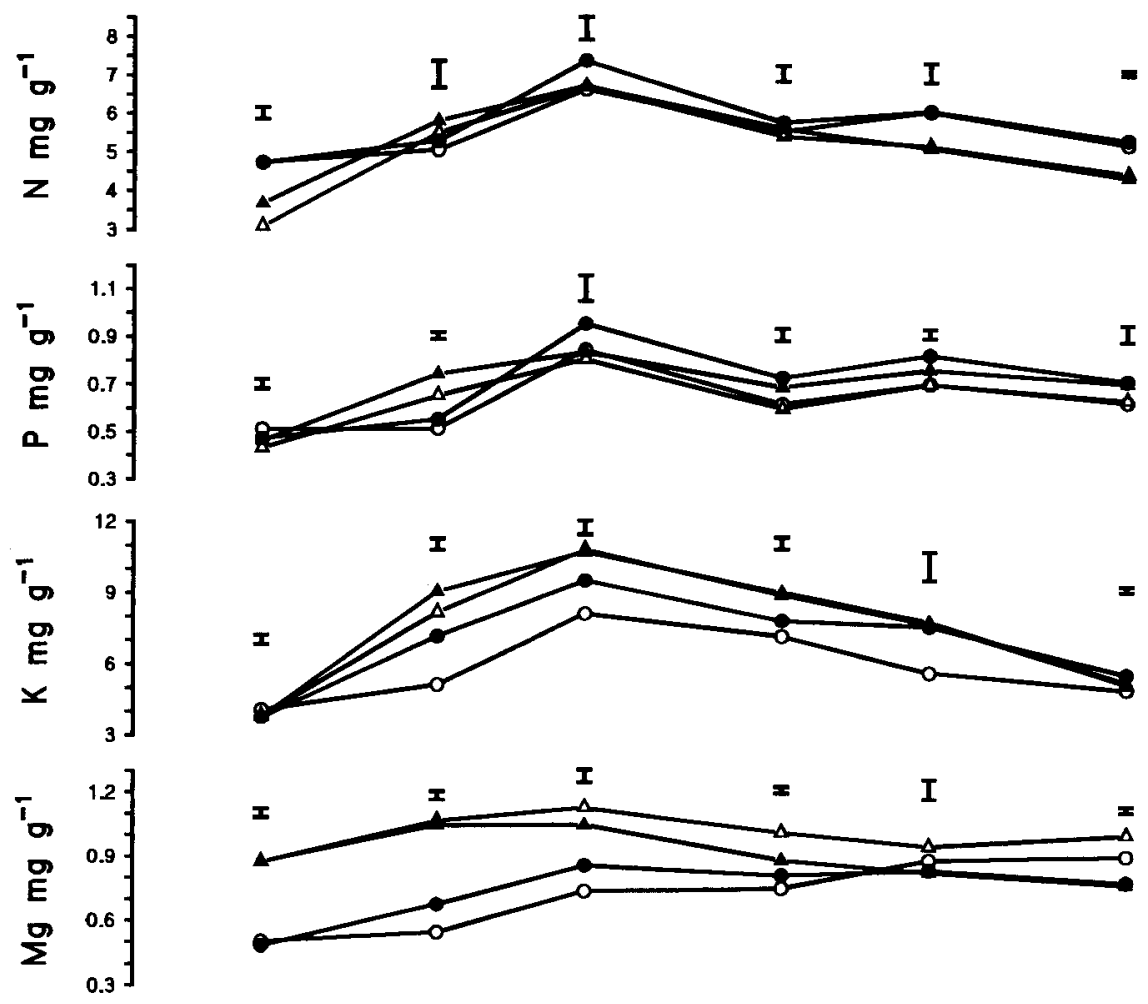

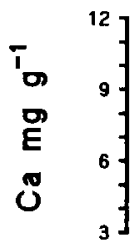
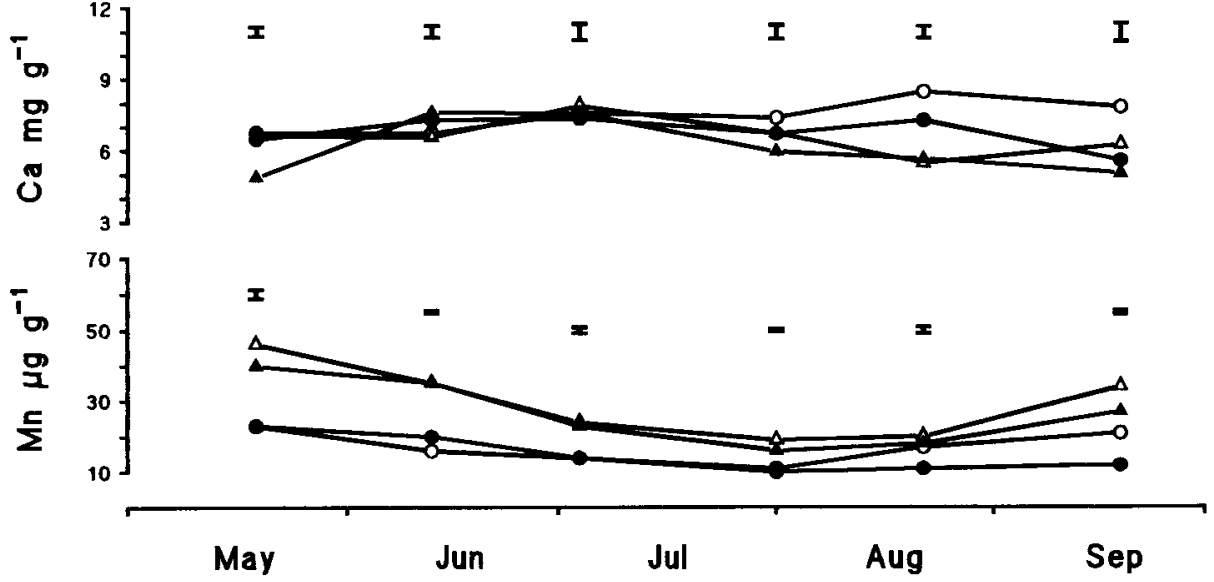

Fig 4. Seasonal time course in 1989 of the mineral concentrations in stems and shoots of $P$ avium and 'Colt' in the 2 irrigation treatments. Vertical bars represent SED $(3 d f) . \triangle P$ avium - irrigation; $\Delta P$ avium + irrigation; $\mathrm{O}$ 'Colt' - irrigation; 'Colt' + irrigation. 
Table V. Effect of irrigation applied in 1990 on the mean growth of $P$ avium and 'Colt' in 1990 .

\section{Irrigation SED}

$-\quad+(96 \mathrm{df})$

Total shoot length $(m)$

$\begin{array}{lrrr}P \text { avium } & 2.91 & 6.00 & \\ \text { 'Colt' } & 10.09 & 16.68 & 0.50\end{array}$

Number of shoots per tree

$\begin{array}{lrrr}\begin{array}{lrr}P \text { avium } \\ \text { 'Colt' }\end{array} & 11 & 13 & \\ \text { Mean shoot length (m) } & 25 & 30 & 1.1 \\ \begin{array}{l}\text { P avium } \\ \text { 'Colt' }\end{array} & 0.27 & 0.50 & \\ \text { Stem diameter (mm) } & 0.43 & 0.58 & 0.02 \\ \begin{array}{l}P \text { avium } \\ \text { 'Colt' }\end{array} & & & \\ & 22.4 & 28.7 & \\ & 27.9 & 35.1 & 0.71\end{array}$

SED for comparison of effect of irrigation within each genotype.

\section{DISCUSSION}

The soil at HRI, East Malling, mineralises approximately $50-70 \mathrm{~kg} \mathrm{~N}^{-1}$ year $^{-1}$ (Greenham, 1976) and a further $40-50 \mathrm{~kg} \mathrm{~N}$ $\mathrm{ha}^{-1}$ year-1 may be deposited from the atmosphere in southern and eastern England (Goulding, 1990). The total uptake of N into the shoots and leaves of the most vigorous trees accounted for approximately 77 $\mathrm{kg} \mathrm{N} \mathrm{ha}^{-1}$ year ${ }^{-1}$. Although, the plants may not have access to all the mineralised nitrogen and some nitrogen is lost through denitrification and by leakage due to drainage, the quantities of mineralised nitrogen were in excess of uptake. Thus, the lack of growth response to nitrogen fertiliser and the large response to irrigation confirms that even for the high density of plants employed in the liner nursery (1989) availability of water was more limiting to growth than a lack of nitrogen. A similar lack of response to a nursery fertiliser application of $80 \mathrm{~kg} \mathrm{~N} \mathrm{ha}^{-1}$
Table VI. The effect of irrigation applied in 1989 on the mineral concentration $\left(\mathrm{mg} \mathrm{g}^{-1}\right.$ dry matter except $\mathrm{Mn} \mu \mathrm{g} \mathrm{g^{-1 }}$ dry matter) in the leaves of $P$ avium and 'Colt' after transplantation, September 1990 .

Effects in 1990 of irrigation applied in 1989

$-\quad$ Irrigation + Mean SED (42 df)

\begin{tabular}{lrrrr} 
N & & & & \\
P avium & 31.0 & 29.4 & 30.2 & 0.73 \\
'Colt' & 29.7 & 28.6 & 29.1 & \\
$P$ & & & & \\
P avium & 2.10 & 1.95 & 2.03 & 0.075 \\
'Colt' & 2.17 & 2.05 & 2.11 & \\
K & & & & \\
P avium & 22.8 & 20.9 & 21.8 & \\
'Colt' & 18.2 & 17.7 & 17.9 & 1.19 \\
Mg & & & & \\
P avium & 1.9 & 2.0 & 2.0 & \\
'Colt' & 3.7 & 3.7 & 3.7 & 0.14 \\
Ca & & & & \\
P avium & 12.0 & 13.7 & 12.9 & \\
'Colt' & 21.1 & 22.3 & 21.7 & 0.87 \\
Mn & & & & \\
P avium & 68 & 66 & 67 & \\
'Colt' & 103 & 94 & 99 & 6.4 \\
\hline & & & & \\
\hline
\end{tabular}

SED for comparison between effects of type of Prunus or irrigation.

to Malus rootstocks was observed by Asamoah (1984).

Leaf water potential of irrigated trees was often low in the field due to high evaporative demand and not necessarily low soil moisture content. Leaf water potentials of fieldgrown irrigated apple trees have also been found to be $<-1 \mathrm{MPa}$ (Higgs and Jones, 1991). Leaf water potentials as low as -1 MPa for the irrigated cherry trees in our experiment did not affect stomatal functioning whereas for the unirrigated trees similar leaf water potentials reduced stom- 
Table VII. Effect of irrigation applied in 1990 on mineral concentration ( $\mathrm{mg} \mathrm{g}^{-1}$ dry matter, except $\mathrm{Mn} \mu \mathrm{g} \mathrm{g}^{-1}$ dry matter) in the leaves of $P$ avium and 'Colt'.

\begin{tabular}{|c|c|c|c|}
\hline & & & $S E D(48 \mathrm{df})$ \\
\hline & - & + & \\
\hline$N$ & & & \\
\hline$P$ avium & 30.0 & 30.3 & \\
\hline 'Colt' & 28.7 & 29.6 & 0.61 \\
\hline $\mathrm{P}$ & & & \\
\hline$P$ avium & 1.91 & 2.15 & \\
\hline ‘Colt' & 1.97 & 2.25 & 0.061 \\
\hline$K$ & & & \\
\hline$P$ avium & 20.1 & 23.6 & \\
\hline 'Colt' & 17.6 & 18.3 & 0.97 \\
\hline $\mathrm{Mg}$ & & & \\
\hline$P$ avium & 2.2 & 1.7 & \\
\hline 'Colt' & 3.8 & 3.6 & 0.13 \\
\hline $\mathrm{Ca}$ & & & \\
\hline$P$ avium & 14.2 & 11.6 & \\
\hline 'Colt' & 23.0 & 20.4 & 1.15 \\
\hline$M n$ & & & \\
\hline$P$ avium & 72 & 63 & \\
\hline 'Colt' & 105 & 93 & 4.0 \\
\hline
\end{tabular}

SED for comparison of effect of irrigation within each cultivar.

atal conductance. Thus, it is unlikely that trees receiving irrigation were unable to transpire and therefore take up nutrients due to excessive drought stress.

In the study reported here all leaf nutrient concentrations of 'Colt' were within the limits generally considered adequate for growth whereas those for $P$ avium were on the borderline for this species (Van den Burg, 1985; Reuter and Robinson, 1986). The concentration of $\mathrm{Mg}$ in leaves of 'Colt' was always greater and the concentration of $\mathrm{K}$ lower than those of $P$ avium, yet no deficiency symptoms were seen. Ystaas (1990) has also reported higher $K$ concentrations in cherry trees on $P$ avium rootstocks than on
'Colt'. Potassium is known to antagonise the uptake of Mg (Mengel and Kirkby, 1982) and low leaf $\mathrm{Mg}$ concentration in fruit trees is often associated with high levels of $K$, even in soil with low available $\mathrm{K}$ (Boynton and Oberly, 1966). From the results of this experiment it is not possible to determine whether the differences in leaf Mg concentration of the 2 genotypes was due to either an intrinsically poorer uptake of $\mathrm{Mg}$ by $P$ avium or a preferred uptake of $K$ which antagonised uptake of $\mathrm{Mg}$ compared with 'Colt'. However, this is the subject of a further investigation which has confirmed that a clonal source of $P$ avium has the same sensitivity to $\mathrm{Mg}$ deficiency as seedling $P$ avium when compared with 'Colt' (Troyanos, unpubished data). Thus, genetic rather than cultural factors influence the susceptibility of cherry to $\mathrm{Mg}$ deficiency and there is potential to use selection and breeding to overcome this problem. This is very relevant to a crop which is unlikely to receive many fertiliser applications.

Irrigation reduced water stress in the nursery and had a positive influence on $P$ and $K$ concentration and a negative influence on $\mathrm{Ca}$ and $\mathrm{Mg}$ concentration in the leaves. Trickle irrigation has been shown to increase the concentration of extractable $P$ in the soil (Bacon and Davey, 1992) and the concentration of $P$ in the leaves of mature fruit trees in some years (Goode and Ingram, 1971; Atkinson, 1986). Atkinson (1986) suggests that apple tree roots under irrigated grass have a limitation to P uptake mid-season compared with roots under bare unirrigated soil due to a reduced total root length, which, in turn, provides fewer sites for infection with vesicular arbuscular mycorrhizae. However, the value of mycorrhizae to field-grown cherries is unknown. In our experiment, irrigation increased leaf $P$ concentration from mid-season onwards and some unreplicated samples of root systems indicated that the root length of both type of cherry was increased in the presence of 
irrigation (data not presented). Other workers have also shown that the root length of Prunus is increased in the presence of irrigation (Richards and Cockcroft, 1975). Grass, a possible source of mycorrhizal infection, was not present in the nursery, so improvement in $\mathrm{P}$ uptake under irrigation was likely to be due to a combination of improved availability from the soil, an increase in size of root system, and reduced water stress. The slight reduction in the concentration of $P$ in the leaves of both types of cherry after transplantation for trees previously irrigated is not readily explicable and requires further investigation.

For $P$ avium the reduction in leaf $\mathrm{Ca}$ and $\mathrm{Mg}$ concentration caused by irrigation was due to a dilution effect as the total foliar content of these minerals did not differ significantly between the irrigated treatments. For 'Colt' the total foliar content of $\mathrm{Ca}$ and $\mathrm{Mg}$ was greater for the irrigated treatment so the reduction in concentration cannot be assigned to a simple dilution effect. The lower $\mathrm{Ca}$ and $\mathrm{Mg}$ concentrations caused by irrigation in the leaves may also have been caused partly by antagonism from the increased $\mathrm{K}$ concentration.

\section{CONCLUSION}

On fine sandy loam, nitrogen fertiliser applied in the nursery had no effect on the growth or leaf nutrient concentration of either genotype either in the nursery or after transplantation.

Irrigation applied in the nursery and after transplantation increases the shoot growth of both genotypes. Thus water availability is more important than supplementary nitrogen in determining the growth and establishment of cherry on this fertile soil.

Irrigation has a differential effect on the nutrient relations of the 2 genotypes. This may be deleterious for $P$ avium with respect to $\mathrm{Mg}$ nutrition where increased growth and $\mathrm{K}$ uptake are apparently not matched by $\mathrm{Mg}$ uptake.

In the year after transplantation the larger trees of 'Colt' that had received irrigation in the nursery produced more total new shoot growth than those previously unirrigated, whereas for $P$ avium there was no difference in subsequent growth. Nursery irrigation was subsequently beneficial for 'Colt' but not for $P$ avium

\section{ACKNOWLEDGMENT}

This project was financed by the Ministry of Agriculture, Fisheries and Food to whom thanks are due.

\section{REFERENCES}

Asamoah TE (1984) Fruit tree root systems: effects of nursery and orchard management and the consequences for growth, nutrient and water uptake. Ph D Thesis, University of London, UK

Atkinson D (1986) The nutrient requirements of fruit trees: Some current considerations. In: Advances in Plant Nutrition Vol 2 (B Tinker, A Lanshli, eds). Praeger, New York, 93-128

Bacon PE, Davey BG (1983) Nutrient availability under trickle irrigation 1. Distribution of water and Bray No 1 phosphate. Soil Sci Soc Amer J 46, 981-986

Bell TIW (1968) Effect of fertilizer and density pretreatment on spruce seedling survival and growth. HMSO, London. For Com For Res 67, 67, $35 p$

Boynton D, Oberly GH (1966) In: Temperate to Tropical Fruit Nutrition (N Childers, ed). Horticulture Publications, New Brunswick, NJ

Duryea ML, McClain KM (1984) Altering seedling physiology to improve reforestation sucess. In: Seedling Physiology and Reforestation Sucess (ML Duryea, GN Brown, eds), Martinus Nijhoff/Dr W Junk Publishers, Dordrecht, 77-114

Forest Industry Committee of Great Britain (1987) Beyond 2000. The Forest Industry of Great Britain. Agriculture House, Knightsbridge, London

Furneaux BS (1954) The soils of East Malling Research Station. In: East Malling Research Station Annual Report for 1953, 67-69 
Goode JE, Ingram J (1971) The effect of irrigation on the growth, cropping and nutrition of Cox's Orange Pippin apple trees. J Hort Sci 46, 195-208

Goulding KWT (1990) Atmospheric deposition. Institute of Arable Crop Research Report 1989, 67, The Lanes Agricultural Trust, cd The University of Bristol, Harpenden, UK

Greenham DWP (1976) The fertiliser requirement of fruit trees. Proc Fen Soc 157, $32 \mathrm{p}$

Higgs $\mathrm{KH}$, Jones HG (1991) Water relations and cropping of apple cultivars on a dwarling rootstock in response to imposed drought. J Hort Sci $66,367-379$

Knight $H$ (1957) Growth and survival of experimental plantations of Douglas fir. British Columbia Forest Service, Victoria, Research Note, 33, $22 p$

MAFF (1981) The analysis of agricultural materials, HMSO, London

Mengel K, Kirkby EA (1982) Principles of plant nutrition. International Potash Institute, Bern, Switzerland

Millard P, Proe MF (1991) Leaf demography and the seasonal internal cycling of nitrogen in sycamore (Acer pseudoplatanus $\mathrm{L}$ ) seedlings in relation to nitrogen supply. New Phytol 113, 587-596

Mullin RE, Bowdery L (1978) Effects of nursery seedbed density and top dressing fertilization on survival and growth of $3+0$ red pine. Can J For Res 8, 30-35
Pryor SN (1988) The silviculture and yield of wild cherry. Forestry Commission Bulletin 75, HMSO, London

Reuter DJ, Robinson JB (1986) Plant analysis - An interpretation manual. Inkata Press, Melbourne, Australia

Richards D, Cockcroft B (1975) The effect of soil water on root production of peach trees in summer. Aust $J$ Agric Res 26, 173-180

Smith JHG, Kozak A, Sziklai O, Walters J (1966) Relative importance of seedbed fertilization, morphological grade, site provenance and parentage to juvenile growth and survival of Douglas fir. For Chron 42 , 83-86

Switzer GL, Neison LE (1963) Effects of nursery fertility and density on seedling characteristics, yield and field performance of Lobboly Pine (Pinus taeda L). Soil Sci Soc Am Proc 27, 461-464

Van den Burg J (1985) Foliar analysis for determination of tree nutrient status - a compilation of literature data. Rapport nr 414 Rijksinstituut voor onderzoek in de bos-enlandschapsbouw. De dorschkamp, Wageningen

Van den Driessche (1984) Soil fertility in forest nurseries. In: Forest nursery manual: production of bare root seedlings (ML Duryea, FD Landis, eds) Martinus Nijhoff/Dr W Junk Publishers, The Hague, 63-74

Ystaas $\rfloor(1990)$ The influence of cherry rootstocks on the content of major nutrients of 3 sweet cherry cultivars. Acta Hort 274, 517-519 